\title{
EL DERECHO HUMANO AL TRABAJO DE LOS MIGRANTES ${ }^{1}$
}

THE HUMAN RIGHT TO WORK OF MIGRANTS

LE DROIT HUMAIN AU TRAVAIL DES MIGRANTES

Ángel Guillermo RUIZ MORENO2*[1

Hay dos tipos de economistas: los que quieren hacer más ricos a los ricos, y los que queremos hacer

menos pobres a los pobres.

José Luis Sampedro

RESUMEN: La historia de la humanidad es la historia de las migraciones que dieran origen a desplazamientos en masa de la población, tanto espontáneo como forzado, e interno y externo; múltiples migraciones han ocurrido desde épocas inmemoriales y por ende no se trata de un fenómeno nuevo. La migración y el trabajo son derechos humanos inalienables e irrenunciables que deberían ser respetados en todo tiempo y lugar, existiendo convenios internacionales, recomendaciones y resoluciones de la OIT que obligan a los Estados miembros a regularle adecuadamente.

\footnotetext{
${ }^{1}$ Recibido el 11 de mayo de 2015 y aceptado para su publicación el 9 de septiembre de 2015.

${ }^{2}$ Doctor cum laude en derecho del trabajo y de la seguridad social por la Universidad San Pablo-Ceu de Madrid, España. Investigador Nacional Nivel III del Conacyt, y profesor investigador de tiempo completo de la Universidad de Guadalajara (UdeG). Coordinador del Doctorado en Derecho y jefe del Departamento de Ciencias Jurídicas de la UdeG. Presidente de la Asociación Iberoamericana de Juristas de Derecho del Trabajo y la Seguridad Social "Dr. Guillermo Cabanellas" (AIJDTSSGC). Presidente de la Academia Mexicana de Derecho del Trabajo y de la Previsión Social (AMDTPS), agruizm@ruizmoreno.com.
} 
Con tratados internacionales se debe pactar la protección integral de los migrantes, mediante la regularización de su permanencia en el país receptor para que cobre salario justo y equitativo, pague impuestos y aporte a la seguridad social, gozando de la debida protección social que atañe al trabajo decente, sin discriminación alguna y con pleno respeto a los derechos fundamentales del operario, igual a lo que disfrutan los nacionales. En caso de no hacerlo, bien podrían usarse las figuras jurídicas de los derechos sociales exigibles al Estado, así como la latencia de derechos en caso necesario.

Palabras clave: Migración laboral; derechos humanos; latencia de derechos; derechos sociales exigibles; protección social.

ABSTRACT: The history of mankind is the history of migrations that gave rise to massive displacements of the population, both spontaneous and forced, and internal and external. Multiple migrations have occurred since time immemorial and therefore is not a new phenomenon. Both migration and labour are inalienable human rights that should be respected at all times and places, with existing International Conventions, Recommendations and Resolutions of the ILO requiring Member States to properly regulate them. It should be agreed by International Treaties that the full protection of migrants, through the regularization of their stay in the host country to be paid a fair and equitable salary, pay taxes and contribute to social security, thus enjoying proper social protection regards decent work, without discrimination and with full respect for the fundamental rights of all workers, equal to that enjoyed by nationals. If not, the legal concepts of enforceable social rights the State might as well be used, as well as latency rights.

Key Words. labor migration; human rights; latency rights; enforceable social rights; social protection.

RÉSUMÉ: L'histoire de l'humanité est l'histoire des migrations qui ont donné lieu à des déplacements massifs de la population, à la fois 
spontanées et forcés, et internes et externes; migrations multiples ont eu lieu depuis des temps immémoriaux et ne sont pas un phénomène nouveau donc. La migration, comme le travail, sont des droits inaliénables et inaliénables qui doivent être respectés en tout temps et les lieux, les conventions internationales, recommandations et résolutions de I'OIT, qui obligent les États membres à regularle adéquatement existants.

Par les traités internationaux doivent être d'accord sur la protection générale des migrants, en régularisant leur séjour dans le pays d'accueil pour le cuivre et équitable des salaires équitables, payer des impôts et des cotisations de sécurité sociale, bénéficiant d'une protection sociale tenant dûment compte de la main-d'œuvre décent, sans discrimination et dans le plein respect des droits fondamentaux de l'opérateur, le même que ceux dont jouissent les ressortissants. Si non, les concepts juridiques des droits sociaux exécutoires l'État pourrait bien être utilisé, ainsi que les droits de latence si nécessaire.

Mots-clés: la migration de travail; droits de I'homme; droits de latence; exécutoire droits sociaux; protection sociale.

SUMARIO: I. Contextualización del tema abordado. II. Los derechos sociales exigibles y la latencia de derechos laborales y de seguridad social. III. Los problemas de la migración para fines laborales y el derecho humano a migrar. IV. El derecho humano al trabajo de los migrantes. Su fuerza jurídica. V. A manera de conclusión.

\section{CONTEXTUALIZACIÓN DEL TEMA}

\section{ABORDADO}

En la segunda década del siglo XXI, resulta evidente que un conjunto de derechos sociales, en cuyo elenco se encuentran el derecho laboral y el de la seguridad social, se han venido modificando en todo el planeta debido al fenómeno de la globalización económica y la enorme crisis financiera conocida como la Gran Recesión, que data de mediados de 2008; todo ello, aunado a un conjunto de políticas de desmantelamiento del otrora mítico 
Estado de bienestar, que sin pudor ni rubor han decidido adoptar los países con economías avanzadas a sugerencia de organizaciones de calado mundial capaces de influir en el resto de los países con sus polémicas recomendaciones netamente economicistas, han puesto en entredicho los derechos fundamentales tanto colectivos como individuales.

En efecto, las dificultades financieras actuales han venido produciendo inexorablemente una sensible reducción de los derechos sociales, lo que afecta a grandes sectores de una población inerme e impotente que mira con nostalgia cómo se desmoronan los otrora magníficos sistemas protectores como el de la seguridad social, en él -para colmo los trabajadores subordinados - habían depositado sus ya frágiles esperanzas de contar con un futuro menos incierto; una seguridad social que, habrá que decirlo, aparte de ser un servicio público cuyo garante primario y final del sistema lo es el Estado, es también un derecho social exigible al Estado aunque la inmensa mayoría de los ciudadanos no entiendan qué es dicha figura jurídica. ${ }^{3}$

No cabe duda que los trabajadores asalariados en México daban por descontado que los derechos pre-adquiridos en el decurso de los años ya nada ni nadie podría quitárselos. Daban por supuesto que las llamadas "reglas del juego" de sus jubilaciones o pensiones -las que provenían desde la época del denominado pleno empleo de los años sesenta y setenta del siglo XX一, tenían la característica inherente de ser eso: "conquistas laborales" inamovibles, obtenidas vía la negociación colectiva laboral y muchas de ellas plasmadas luego en la propia norma legal, máxime que estaba plasmada en los incisos g) y h), de la fracción XXVII, del Apartado "A" del artículo 123 de nuestra propia Constitución Política de los Estados Unidos Mexicanos (CPEUM), la figura jurídica de la irrenunciabilidad de derechos laborales y de protección social.

\footnotetext{
${ }^{3}$ Ruiz Moreno, Ángel Guillermo, “Los derechos sociales exigibles al Estado. Una aproximación conceptual", El derecho social a inicios del siglo XXI, México, Universidad de GuadalajaraPorrúa, 2007, pp. 1-20.
} 
Se equivocaban los operarios y sus sindicatos, e incluso nos equivocamos también los juslaboralistas y segurólogos sociales que dábamos como un hecho que no habría marcha atrás; porque México, pionero en materia de los derechos sociales en su mítica Constitución de 1917, era ejemplo mundial en el tema. Sin embargo, desde el último cuarto del siglo $X X$, siguiendo dichas tendencias mundiales, se comenzó a dar un brusco viraje a las políticas públicas del empleo y de la protección social que le acompañaba —previsión y seguridad sociales-, reformándose las legislaciones federales que regulaban tales materias tanto para el trabajo ordinario como del burocrático.

Algunos botones de muestra que demuestran nuestra afirmación:

a) Mediante la expedición de la nueva Ley del Seguro Social (LSS) y la del Instituto del Fondo Nacional de la Vivienda para los Trabajadores (Infonavit) de mediados de 1997, se cambió radicalmente la manera de entender este sistema protector social, muy en especial en el rubro pensionario en donde la responsabilidad se dejó al cargo exclusivamente del operario asegurado.

b) La trascendente reforma efectuada a la Ley del Seguro Social de diciembre de 2001, cuando se reformó el texto original en sus dos terceras partes de un día para otro y sin hubiera siquiera un espacio de vacatio legis para que la gente se diera cuenta de su importancia; mediante el Decreto del 20 de diciembre, el Congreso de la Unión estableció nada menos que 20 delitos, en una peculiar reforma donde el IMSS perdió para siempre su careta social para convertirse en un temible ente fiscalizador autónomo.

c) La reforma burocrática de abril de 2007, que demostraría el palpable abandono por parte del Estado mexicano tanto para con su compromiso patronal como el mayor empleador del país que es -con más de dos millones de empleados públicos-, como su impotencia para sostener el esquema pensionario de seguridad social que antaño parecía "blindado" para los servidores públicos federales; ello daría pie a que luego se hiciera lo mismo con los sistemas estaduales de seguridad social de las entidades 
federativas-. Dicha reforma homologó la Ley de Seguridad y Servicios Sociales de los Trabajadores del Estado (ISSSTE), con la LSS en su versión de 2001 precitada en el inciso anterior.

d) Y mediante la utilización de una novedosa figura de Iniciativa Preferente que de suyo merecería un estudio jurídico entero, aprovechando el cambio de estafeta del titular del Ejecutivo federal - pero dejando intocado sorprendentemente el obsoleto artículo 123 de la CPEUM-, se consiguió reformar al fin la Ley Federal del Trabajo (LFT) el 10. de diciembre de 2012, la que ha sido cuestionada por el sector patronal, sindical y el académico, cuyo primordial objetivo no es otro que aumentar la productividad nacional mediante la flexibilidad contractual, cambiándose su texto en una tercera parte.

Hasta aquí este breve cuanto ejemplificador recuento del viraje en asuntos sociales de gran calado, sin dejar de señalar que tales reformas legales fueron avaladas -y luego legitimadas- por los propios tribunales jurisdiccionales, incluida obviamente la Suprema Corte de Justicia de la Nación. ${ }^{4}$

\section{LOS DERECHOS SOCIALES EXIGIBLES Y LA LATENCIA DE DERECHOS LABORALES Y DE SEGURIDAD SOCIAL}

Es por ello que los trabajadores y sus sindicatos hoy día, se ven impotentes para preservar derechos cuasi adquiridos (todavía no son derechos adquiridos porque les falta aún un breve lapso para su total consumación... pero sucede que de repente se interrumpe su cómputo final debido a un cambio intempestivo legal, lesivo a los intereses del individuo), y sin que la figura jurídica de la latencia de derechos, tan poco explorada y analizada en México, sea plenamente conocida y reconocida a pesar de la prohibición

\footnotetext{
${ }^{4}$ La injerencia del Poder Judicial con los otros dos poderes es muy obvia. Al XXI se le ha llamado con razón "el siglo de los jueces", pues vía jurisprudencia se hacen interpretaciones extensivas y de alcance a todo tipo de normativas, incluido aquí el texto de preceptos constitucionales y hasta convenios internacionales; labor donde en el mundo entero la constante es que los impartidores de justicia se arroguen una atribución legislativa.
} 
expresa establecida en el primer párrafo del artículo 14 de nuestra CPEUM, acerca de la aplicación retroactiva de normas legales en perjuicio del gobernado. Queda demostrado entonces que ya todo es negociable y renegociable en este deshumanizado mundo de economía globalizada donde, aduciéndose siempre factores económicos, se cambian "las reglas del juego durante el juego", contándose para ello con la aprobación o permisivismo de los representantes de los poderes del Estado.

Empero, contrario a lo que las mayorías suponen, no sólo hay derechos adquiridos y expectativas de derecho, sino una figura jurídica intermedia casi ignorada: la latencia de derechos (es decir, derechos que han dejado de ser simples expectativas y que aún no se terminan de completar por simples razones de tiempo, los que también existen aunque todavía no se consumen, igual como sucede con el embarazo de una mujer: si bien el feto no ha nacido y no es todavía una persona humana independiente, tanto la madre como el feto están ya protegidos por el derecho pues el producto del embarazo tiene derecho a la vida). ${ }^{5}$ Lástima que la latencia de derechos sociales no son reconocidos aún en el país, contraviniéndose no sólo el artículo 123 sino el propio artículo 10. de nuestra carta fundamental, ignorándose de plano los principios de supremacía constitucional y pro persona, así como el control difuso y el de convencionalidad, por los operadores de la justicia mexicana. Así, ante tan dura realidad, la justicia social ha dado ya pruebas fehacientes a lo largo y ancho del orbe, que el tema no está dentro de las prioridades de casi ningún Estado nacional.

En tan inquietante contexto, como sociedad nos terminamos equivocando todos, gobernantes y gobernados, y como ahora, carentes ya de valores morales y éticos, el fin justifica los medios para alcanzarlo, queda pues en entredicho el Estado de derecho.

\footnotetext{
${ }^{5}$ Véase "La idea de los derechos latentes laborales y de seguridad social, ante eventuales cambios legislativos. Una aproximación conceptual", Revista Latinoamericana de Derecho Social, UNAM, Instituto de Investigaciones jurídicas, núm. 8, enero-junio de 2009, pp. 299-322, disponible en http://biblio.juridicas.unam.mx/revista/pdf/DerechoSocial/8/art/art8.pdf.
} 
Opinamos que lo que se requiere es que haya más compromiso y regulación por parte del Estado, para que ponga freno y regule mejor al mercado - mercado lo hay en casi todos los asuntos sociales de gran calado: de trabajo, de salud, de pensiones, educativo, etcétera-, generando así seguridad y certeza jurídicas porque los seres humanos requerimos de sistemas sólidos de protección de la más diversa índole, sobre todo ahora, en épocas de necesidad. Ese es, a nuestro entender como estudiosos e investigadores del tema, tal vez el mayor problema estructural que afronta a inicios de la segunda década del siglo XXI el empleo digno, conjuntamente con una seguridad social sólida y confiable que debería acompañarle siempre.

Es posible entonces que al querer avanzar de prisa y acaso sin pretenderlo —esto último, siendo sinceros, resulta improbable pues en política no hay casualidades sino causalidades-, hemos retrocedido hacia una concepción decimonónica en el asunto de la protección social genérica en todo el planeta, según la cual, el bienestar individual y colectivo se entienden como un asunto privado y de estricta responsabilidad personal e intrafamiliar; todo ello mientras los representantes de los poderes del Estado "se lavan las manos" y voltean hacia otro lado para no ver el problema humano y social provocado, rehuyendo así a su responsabilidad natural inherente a tan elevados encargos públicos.

Por lo tanto, la acción pública, en vez de pensar en renovadas políticas de largo alcance que establezcan un marco cierto de actuación gubernamental, ha quedado reducida en la práctica a simples programas asistencialistas, para colmo temporales y discrecionales, enfocados a procurar una relativa protección sólo a sectores ancestralmente marginados y excluidos sociales del país; mientras que las clases medias -que por cierto son el mayor número de contribuyentes cautivos y quienes proporcionalmente pagan más impuestos para costear dichos servicios públicos-, se les ignora.

No sorprende entonces que el desempleo real sea un fantasma que espanta a la gran mayoría de las sociedades contemporáneas, y ello explica el 
porqué México tiene un sector informal cercano al $60 \%$ de su población en edad activa; de tal manera que el total recargamiento - por no decir descargamiento- en los sistemas públicos de la seguridad social que acompañaban a la otrora magnífica previsión social laboral, que antaño se negociaba contractualmente entre empleadores y sus sindicatos en un abierto y distendido diálogo social (un asunto éste que tanto lustre diera en sus momentos más gloriosos al derecho del trabajo, en la segunda mitad del siglo XX), hoy sea una especie en vías de franca extinción debido a una serie de factores de la más diversa índole, entre los cuales se encuentran, amén de las crisis económicas y financieras ya citadas en párrafos precedentes, entre muchas otras causas:

- Las nuevas formas laborales y de producción por el uso de la híper tecnología.

- La evidente atomización sindical y el declive de los sindicatos como genuino interlocutor en el diálogo social.

- El imparable incremento del desempleo en todo el mundo.

- La falta de políticas públicas nacionales de largo aliento que generen condiciones e incentivos fiscales y administrativos para creación de empleo decente permanente y no precario.

- El crecimiento exponencial del sector informal de la economía, mediante la tercerización de servicios que en muchos casos es un fraude a la legislación laboral, socavando los cimientos de la seguridad social que le acompaña.

- Las imparables migraciones para fines laborales, que se han convertido en un verdadero quebradero de cabezas tanto para países receptores como los expulsores de emigrantes

- El ataque frontal que han sufrido desde inicios de la década de los años ochenta del siglo XX los sistemas de seguridad social, en una callada tarea de zapa de desmantelamiento que no pasa desapercibida a los versados en el tema. 
- El planteamiento de la falsa tesis economicista, imperante en todas las latitudes, que pregona que el servicio público de la seguridad social es ya infinanciable en el siglo XXI.

En ese mismo hilo de ideas de la seguridad social, aduciendo su impagable coste, paradójica e inexplicablemente ha sido el propio Estado -quien por cierto creó ex profeso a los seguros sociales para que se ocuparan de brindar a la ciudadanía el servicio público de la seguridad social-, el que ha provocado o al menos permitido su desmantelamiento sistemático, abandonándoles a su suerte; o para decirlo más claro todavía: ha sido el propio Estado, movido o atraído por la fuerza que cobró el "dios mercado", sic, en el primer tramo de este siglo, quien intentando escapar por la puerta trasera lo más sigilosamente posible de sus responsabilidades naturales, previstas de manera expresa en el artículo 22 de la Declaración Universal de los Derechos Humanos (DUDH), ${ }^{6}$ acaso confiando en la desmemoria de los ciudadanos.

No hay duda entonces: hace falta más Estado y menos mercado, máxime cuando éste ya demostró, desde finales del siglo pasado, que no es capaz de regularse a sí mismo como sostenían los economistas, y por ende requiere dicho mercado - sea nacional, regional, continental o internacional- ser eficazmente regulado siempre, de manera global, por los poderes públicos del planeta.

Así las cosas, en este inquietante diagnóstico situacional, las preguntas pertinentes a formular ahora serían: ¿qué subyace en todo esto, que ha trastocado la compleja realidad actual, impidiendo que el derecho social pueda cobrar la relevancia que merece para proteger los derechos humanos irrenunciables e inalienables de la ciudadanía? ¿Cuál fue la causa de ello, la ignorancia o la mala fe? Y la respuesta buscada acaso sea que ambas, pues juntas son dinamita pura... sin dejar de observar apatía e indiferencia de una

\footnotetext{
${ }^{6}$ Declaración Universal de los Derechos Humanos, Organización de las Naciones Unidas, disponible en http://www.un.org/es/documents/udhr/(consultada el 23 de abril de 2015).
} 
política torpe que se escuda en las "razones de Estado", sic, que suelen aplicarse cuando el Estado carece de razón.

En resumidas cuentas, sin políticas públicas humanistas de largo alcance que ubiquen a la persona humana en el centro de la actuación gubernamental, contando con la oportuna labor legislativa y la jurisdiccional, permea en nuestro país una preocupante displicencia acerca de los asuntos sociales de gran calado desde hace ya un cuarto de siglo; de lo que se deduce sin esfuerzo que los factores políticos y económicos son cruciales para que esta situación persista a pesar de las advertencias que lanzamos cotidianamente, basadas en cifras y datos duros, los cada vez menos cultores del derecho social, una rama jurídica que se encuentra hoy día en el arcón del olvido y que reaparece en épocas pre electorales cada trienio o sexenio, cuando la clase política se acuerda de que el ciudadano vota.

Habrá que decirlo entonces fuerte y claro para que mejor se entienda el punto: el gastado discurso político, que intenta disfrazar esta dura realidad, demuestra la falta de sintonía con lo que el pueblo soberano necesita, tal vez porque todavía no se ha terminado de entender que la época del pleno empleo ya se fue y que difícilmente volverá; que la autocupación o trabajo autónomo sustituyen hoy al empleo subordinado, y muestra de ello es el crecimiento exponencial de la informalidad; que en ese complicado contexto global, es incongruente y hasta pernicioso intentar tercamente seguir atando a la seguridad social al empleo formal —como se hizo en la reforma laboral mexicana de diciembre de 2012-; que guste o no, la migración laboral es una realidad innegable y en no pocas ocasiones es la única esperanza que tienen millones de habitantes de este planeta -entre ellos, cómo no, millones de mexicanos-; y que el ingente coste de la seguridad social no es un gasto sino una inversión en lo mejor que tiene un pueblo, que es su gente. ¿De veras será tan complicado entender nuestra dura realidad nacional?

\section{LOS PROBLEMAS DE LA MIGRACIÓN PARA FINES LABORALES Y EL DERECHO HUMANO A MIGRAR}


Todos sabemos que la migración es un fenómeno constante y de larga data en la historia de la humanidad. Ha sido así como se han construido nuestras sociedades contemporáneas a lo largo de los siglos, si bien a últimas fechas -acaso por la enorme valoración que en el rubro de los derechos humanos se ha conseguido a partir del 10 de diciembre de 1948 con la emisión de la DUDH - se le ha dado al tema migratorio para fines laborales una enorme importancia; un tema que poco a poco ha ido construyendo una nueva cultura social para comprender de mejor manera este complejo tema de múltiples aristas, el que durante décadas fue sencillamente ignorado por los juristas.

Adelantamos que para abarcar en su totalidad las distintas facetas de este asunto de gran actualidad mundial, se necesitarían bibliotecas enteras capaces de plasmar y retratar, desde sus distintos perfiles: histórico, político, geográfico, filológico, social, económico o jurídico, este asunto de gran calado, convergiendo, mediante la investigación interdisciplinaria seria y objetiva, disciplinas científicas capaces de generar en un diagnóstico situacional serio y objetivo, no tanto para saber lo que hubo antes en materia de migración laboral, sino más bien para comprender el fenómeno y lo que está por venir.

Las estadísticas migratorias son demasiadas como para intentar siquiera delinearlas ahora, al igual que son complejos los cambios demográficos que, al paso del tiempo, se han generado a partir de la peculiar manera en como países y continentes enteros se fueron poblando, hasta llegar a ser el mosaico de razas y etnias que hoy pueblan el orbe. Nos limitaremos entonces, por simples razones metodológicas y de espacio, al tema migratorio observado únicamente desde su perfil de derecho humano, y del fenómeno de la migración para fines laborales, en razón de lo cual no abordaremos aquí la temática de los refugiados ni otros subtemas análogos.

Para comenzar, demos por sentado que el derecho a migrar tanto interna como internacionalmente, es un derecho humano incorporado desde hace más de medio siglo al catálogo de los derechos fundamentales vigentes al ser la denominada libertad de tránsito un derecho humano, reconocido como tal 
por el artículo 13 de la DUDH de la Organización de las Naciones Unidas (ONU), precepto que en síntesis alude a nuestra libertad de movimiento y cuyo texto previene claramente:

1. Toda persona tiene derecho a circular libremente y a elegir su residencia en el territorio de un Estado.

2. Toda persona tiene derecho a salir de cualquier país, incluso del propio, y a regresar a su país.

Si lo anterior lo vinculamos al derecho al trabajo que todos tenemos como individuos libres, mismo que es consagrado por el artículo 23 de la aludida DUDH, entonces la conclusión es obvia: la migración es un derecho humano, por más que el derecho vigente emanado de los órganos del Estado emisor o receptor pretenda regularle, condicionarle, restringirle o impedirlo. Porque el aludido artículo 23 establece:

1. Toda persona tiene derecho al trabajo, a la libre elección de su trabajo, a condiciones equitativas y satisfactorias de trabajo y a la protección contra el desempleo.

2. Toda persona tiene derecho, sin discriminación alguna, a salario igual por trabajo igual.

3. Toda persona que trabaja tiene derecho a una remuneración equitativa y satisfactoria, que le asegure, así como a su familia, una existencia conforme a la dignidad humana y que será completada, en caso necesario, por cualesquiera otros medios de protección social.

4. Toda persona tiene derecho a fundar sindicatos y a sindicarse para defensa de sus intereses.

De manera entonces que el derecho a migrar, al igual que el derecho a trabajar, no son derechos otorgados o denegados por algún Estado a sus ciudadanos, sino son derechos humanos inherentes a la propia persona humana como tal, derechos fundamentales que han sido ya reconocidos en la gran mayoría de las legislaciones contemporáneas, siempre más allá de lo 
que el concepto esquivo e inasible de "soberanía nacional" signifique hoy día en un mundo global de fronteras nacionales diluidas y porosas.

En un mundo globalizado e interconectado tecnológicamente como el actual, en teoría ninguno de los países del planeta -formen o no parte integrante de la ONU—, no pueden ni deben jurídicamente prohibir, ni válidamente impedir, las migraciones humanas sean nacionales 0 internacionales; regularlas desde luego sí que pueden en razón de su soberanía, pero deberán hacerlo en todo caso con objetividad y con sentido humanitario, mas no prohibirlas ni impedirlas por la fuerza pues a golpe de decretos, normativas u ordenanzas locales, de muros y cercas electrificadas, es imposible modificar la realidad mundial: la gente ha migrado y seguirá haciéndolo siempre.

Al punto habrá que recordar que, si bien existen opiniones divergentes, la DUDH ha sido repetidamente reconocida como lo que en realidad es en vez de un simple catálogo declarativo: un genuino instrumento jurídico vinculante para todos los Estados del planeta - sean miembros o no de Naciones Unidas-. Sobre este tópico, siempre polémico pero hoy más actual que nunca, jerarquizando en su análisis una interpretación pro persona, hay múltiple literatura jurídica consultable y la enorme mayoría debe de concordar en dicha fuerza vinculante de la DUDH, especialmente si consideramos el texto del artículo 10. de la CPEUM que le da al control de convencionalidad una categoría trascendente a las normativas internacionales por sobre las nacionales, tal y como a últimas fechas ha reconocido la Suprema Corte de Justicia de la Nación. ${ }^{7}$

La historia de las migraciones es la historia de la humanidad misma, se ha dicho en repetidas ocasiones, y eso es un hecho tan evidente que no requiere de prueba alguna, de tal suerte que si la migración es añeja historia humana,

\footnotetext{
${ }^{7}$ Se sugiere al lector analizar el estudio efectuado por el gran jurista uruguayo Héctor Gros Espiell acerca de la fuerza jurídica vinculante de la DUDH, disponible en http://biblioteca.itam.mx/estudios/90-99/91/hectorgrosespiel/unamiradaactualala.pdf (consultada el 24 de abril de 2015).
} 
y el derecho también es inherente a la historia de las sociedades, será necesario entonces comenzar por entender en su exacta dimensión los derechos humanos cuando se analice el tema de la migración para efectos laborales, a fin de no incurrir en la tentación de "satanizar" prejuiciosamente el tema, frente a la evidencia innegable de que el derecho a circular y por ende migrar es, en razón de su naturaleza intrínseca, inalienable e irrenunciable.

Sin embargo, las negativas del derecho a migrar observadas durante las últimas décadas - sobre todo en países desarrollados-, es una constante a la que se suman las normas de carácter internacional que implícitamente ignoran el derecho a migrar; así las cosas, la decisión de desconocer este derecho humano a la migración es más bien de índole político que no jurídico, con todo lo que ello significa e implica. Sería mejor entonces cobrar de una buena vez plena conciencia acerca de su existencia y de la dificultad que entraña impedirla, siempre más allá de lo que pensemos o creamos al respecto pues sus características o modalidades cambian también de manera constante.

Conviene precisar aquí, para una mayor claridad, que no son ni implican lo mismo, por ejemplo las migraciones forzadas de esclavos, que la de refugiados por razones políticas o de guerra, que suelen ser temporales o coyunturales; ${ }^{8}$ las que a su vez son diferentes de las voluntarias migraciones para fines laborales que tienen la característica de ser permanentes -ya por razones históricas o de simple tradición-, aunque existan “picos" en las estadísticas debido a motivos económicos y de subsistencia.

\footnotetext{
${ }^{8}$ Sin duda las migraciones son elemento esencial de la vida humana en sociedad que en el decurso de milenios definió tanto a las sociedades como a la idiosincrasia regional o nacional. La misma historia de la humanidad calcula que el fenómeno de las migraciones sucede de manera constante desde hace unos doscientos mil años... por lo que es anterior incluso a la existencia misma de cualesquier antecedente social, a las naciones actuales $y$, en especial, del Estado como creación humana de organización social.
} 
Por lo tanto, no es igual que un individuo emigre en búsqueda de mejores oportunidades de vida, empleo e ingreso y con la idea en mente de regresar por o con los suyos, a que migre por gusto hacia un país que le es más atractivo para vivir. Tampoco es lo mismo migrar legalmente con los papeles en regla, que irse sin papeles a buscar trabajo a otro país, pues en muchos de los casos no es igual ser ilegal que carecer de papeles para laborar. Y es también muy diferente de todas las anteriores modalidades, la migración externa o internacional, con respecto de la migración interna o nacional esto es, cuando se trasladan individuos del área rural a la ciudad o de ésta al campo, una migración que estadísticamente es más copiosa que la internacional-. Cada una de tales opciones y sus múltiples variantes representan en la práctica desafíos enormes qué atender, problemáticas que deberán resolverse de forma diferenciada -o mejor aún: jurídicamente diferenciada- pues, en el fondo, se trata de un tema prioritariamente humano y social antes que jurídico, debido a su característica intrínseca de ser un derecho fundamental. ${ }^{9}$

No obstante, lo que sí nos queda muy claro es que cada caso es distinto entre sí y por tanto requiere de soluciones diferentes, pues no existen "recetas" para atender estos desafíos que plantea, la mayor de las veces intempestivamente, la compleja realidad cotidiana.

Así, la costumbre de trasladarse de un lugar a otro data desde los más remotos orígenes del ser humano -especialmente cuando éste se dio cuenta que era mejor vivir en una sociedad organizada y buscó cómo insertarse en

\footnotetext{
${ }^{9}$ Hay migraciones que son movimientos espontáneos de reagrupamiento de poblaciones que por alguna causa han sido divididas, o bien existen otras que no han tenido más alternativa que migrar debido a desastres naturales. En América Latina hubo un notorio proceso de migración interna del campo a las áreas urbanas, alrededor del mediados del siglo XX, lo que coadyuvó a la creación de grande urbes pero con notorios cinturones de miseria; los casos más emblemáticos lo son: el Distrito Federal (México), Sao Paulo (Brasil), Buenos Aires (Argentina) o Caracas (Venezuela), si bien al menos las tres primeras ciudades nombradas también recibieron notorias migraciones internacionales, lo cual representó un doble desafío para las población nativa y sus gobernantes.
} 
ella-, buscando cumplir la anhelada meta de realización personal a la que aspira todo ser humano. Acaso lo que más llama la atención es que inmersos los individuos, por costumbre o por necesidad, en migraciones milenarias, es que en pleno siglo XXI el fenómeno pueda parecerle a alguien nuevo, o que se sorprenda de su expansión exponencial incontenible, o le extrañe que sea considerado un enorme "problema contemporáneo". Si esto último se da es porque, por increíble que pueda parecernos, hay todavía Estados que carecen de eficientes controles migratorios y adolecen de políticas nacionales efectivas, capaces de afrontar los grandes flujos migratorios hacia países con mejor posicionamiento económico global de quienes buscan una sola cosa: trabajo - formal o informal, acaso las dos caras de la misma moneda-, pero trabajo al fin.

Es obvio pues que nadie puede ser obligado a permanecer atado a su país de origen ni en ningún otro país, si en pleno ejercicio de su libre albedrío decide emigrar, así no cumpla el emigrante con las normativas migratorias vigentes en el país elegido para ello; obviamente que alcanzamos a distinguir, entre lo que es la migración legal de la ilegal, y bien entendemos que nuestro derecho personal no puede estar jamás por encima del derecho soberano de los distintos países del orbe, jurídicamente autorizados para fijar condiciones de internamiento a su territorio y las reglas para trabajar en el país de acogida. Como nos queda perfectamente claro que ningún derecho es absoluto -incluidos los derechos fundamentales de los seres humanos-, como también nos queda claro que a cada derecho corresponde una obligación.

Sucede entonces que entre el derecho a migrar y la soberanía de un Estado, existe un conflicto jurídico complicado de resolver en la práctica al intentar satisfacerlos ambos, pues no es sólo el derecho nacional el que opera y sirve de regulación jurídica en estos casos, sino también aplican las normativas internacionales vigentes - que integran por cierto el entramado de la estructura jurídica de cada país, de conformidad a su propia Constitución política-. ¿Cómo podemos empatar entonces ambas regulaciones legales? 
Pues bien, el punto medular de este asunto, cuando se estudia el problema migratorio laboral —visto y entendido a la par como un asunto económico y social, con implicaciones jurídicas-, es que cuando ocurre la migración laboral sin sujetarse a las normativas existentes en el país que recibe a un individuo o a su familia, se traduce, quiérase o no, en una migración ilegal que provoca múltiples problemas de la más diversa índole, incluso en un momento dado hasta de seguridad nacional. Y que conste también: el hecho de trabajar no es propiamente la actividad ilegal, sino en esencia lo es la residencia o estadía indebida en territorio extranjero sin tener el permiso correspondiente de las autoridades del país receptor. ${ }^{10}$

Empero, más allá de la eventual legalidad o ilegalidad de la estadía en un país extranjero, antes de emitir juicios contundentes habrá que recordar que estamos frente a derechos humanos fundamentales, como lo son los derechos a trabajar y a migrar; derechos ambos que, en todos los casos, deben ser respetados y considerados por los países receptores o de paso sin prejuicios de la nacionalidad que fuere el migrante, porque ambos derechos — como ya se dijo antes-, son connaturales a nuestra condición de persona humana.

Es posible que la falta de controles fronterizos internacionales adecuados, en buena medida se deba a la existencia de las "fronteras virtuales" que hoy existen como resultado lógico de los múltiples tratados internacionales de libre comercio en un mundo de globalización en todos los órdenes. Porque los sistemas de monitoreo, censo y control que llevan los países hoy día, no parecen suficientes ante la fuerte corriente migratoria laboral... un fenómeno mundial que cada quien interpreta a su manera y que no pocas veces se manipula a conveniencia por factores políticos. Por ello es que -como suele suceder en asuntos sociales de gran calado-, el tópico migratorio está

\footnotetext{
${ }^{10}$ Eso explicaría - que no justificaría, conste-, por qué muchos usan a los migrantes para lucrar con su internamiento a un país extranjero, por qué se propicia el delito de "trata de personas" abusando de su frágil condición de "sin papeles", y por qué suele esconderse detrás de ellos el crimen organizado.
} 
siempre rodeado de mitos y de verdades a medias que terminan tergiversando los hechos y pueden, en algún momento, afectar nuestra percepción de ella, máxime cuando convergen ambos temas: migración e informalidad laboral. ${ }^{11}$

Después de todo consideremos, como bien lo explica Miguel Ángel Fernández Pastor, ex director del Centro Interamericano de Estudios de Seguridad Social (CIESS):

Todo trabajador que migra es, de algún modo, un llamado de atención y un grito de esperanza. Cuando una persona decide cruzar las fronteras de su país abandonando a su grupo primario de contención, la familia, lo hace porque siente que en su medio no tiene posibilidades de progreso. Pero también lo encara con la expectativa de construir un futuro mejor. Migrar es un atreverse a lo desconocido, a la ventura, pero también es animarse a construir una utopía posible, cual es la de crecer y desarrollarse. Por eso, ese atreverse merece el amparo tanto del Estado expulsor como del Estado receptor. Del Estado expulsor, porque éste no ha sabido darle el marco de contención necesario, y del Estado receptor porque será ahí donde aportará toda la capacidad creativa y laboral de que dispone. ${ }^{12}$

Así las cosas, a fin de estar en posibilidad de formular propuestas viables y factibles, frente a la necesidad de dotar de mecanismos efectivos de protección social a los trabajadores migrantes -en el caso mexicano, haciendo una interpretación acorde con lo estatuido por el segundo párrafo del artículo 10. de nuestra CPEUM, en materia de derechos humanos-, que, insistimos, es la variante de migración que más nos ocupa y preocupa-, habrá que entender el entorno y las circunstancias particulares del problema, para comenzar evitando el uso de la fuerza y la "criminalización" de la

\footnotetext{
${ }^{11}$ Al lector interesado le sugerimos la lectura del libro de nuestra autoría intitulado: Seguridad social obligatoria para trabajadores migrantes e informales, México, Porrúa, 2011.

12 Fernández Pastor, Miguel Ángel, La protección social de los trabajadores migrantes mexicanos, pról. de Gabriela Mendizábal Bermúdez, México, Juan Pablos Editor, 2009, p. 11.
} 
migración laboral, lo cual requiere de una política pública inteligente específica.

Los Estados "tradicionalmente expulsores de migrantes —como México-, junto con los países de arribo —como en nuestro caso los Estados Unidos de América-, compartiendo 310 kilómetros de frontera común, tienen grandes desafíos y múltiples tareas pendientes por acometer, que requieren, sobre todo, de "cambiar el chip" acerca del tema migratorio, que beneficia tanto a ambos países. Entre otros, deberían de estar a nuestro entender los siguientes temas:

- Acuerdos migratorios actualizados al siglo XXI, ajustados a la normatividad internacional de la propia OIT, que ofrezcan la efectiva ayuda internacional entre países vecinos (el caso específico MéxicoEstados Unidos es paradigmático).

- Registro sin prejuicios de los individuos que en uso de su libertad deseen migrar.

- Políticas públicas de apoyo básico tanto para los emigrantes, como para los inmigrantes, atendiendo a su escolaridad, condición social y económica, así como situación familiar.

- La promoción del empleo digno y con seguridad social incluida, tanto en el país receptor como en el expulsor, acompañado siempre de gestiones consulares eficaces que aseguren al connacional al menos un piso básico de protección social. ${ }^{13}$

- Programas públicos de control del trabajo autónomo o autocupación, esencialmente para fines de protección social de los trabajadores por cuenta propia.

\footnotetext{
${ }^{13}$ Para una mayor información sobre el tema de los pisos básicos de protección social de la ONU, OMS y OIT, véase el PDF "Pisos de protección social para la justicia social y una globalización equitativa", disponible en http://Www.ilo.org/wcmsp5/groups/public/---ed_norm/--relconf/documents/meetingdocument/wcms_160399.pdf(consultada el 10. de mayo de 2015).
} 
— Incubadoras de negocios, orientadas a los temas de quienes deseen migrar.

- Instrumentación de programas de créditos blandos y con bajos intereses, para establecer micro empresas (micro empresarios a quien se les trate como trabajadores, y no como empresarios). ${ }^{14}$

- Todo tipo de facilidades administrativas e incentivos fiscales para que los emprendedores abran sus propios negocios en el país expulsor, dándole la oportunidad al nacional de que se quede, en vez de que migre.

- Financiamiento permanente del Estado para las labores del campo y la agroindustria, que las impulse y vuelva redituables.

- Otras medidas administrativas que impidan la salida de los nacionales y eviten en lo posible el fenómeno migratorio, entre ellas haciéndose un especial énfasis en la educación previsional.

Se trata, en resumen, de un grave problema en donde lo humano, lo social, lo económico y lo jurídico inevitablemente convergen, el que será irresoluble en tanto no se busquen adecuadas e inteligentes alternativas de solución que - para decirlo metafóricamente y mejor se entienda la idea-, focalicen la raíz del problema y no sólo se queden en las ramas o en el follaje del árbol. Hablamos aquí nada menos que de combatir las causas de la migración internacional, y no sólo sus perniciosos efectos.

\footnotetext{
${ }^{14}$ El notable juslaboralista Mario Pasco Cosmópolis, ex ministro del Trabajo del Perú, recientemente fallecido, en la conferencia inaugural del "VI Congreso Iberoamericano de la AIJDTSSGC, Trujillo-2009", presentó una tesis interesantísima de analizar de lo que él llamó Un derecho laboral para los informales. Pasco propuso que los micro empresarios sean considerados por el Estado (esto es: el fisco, las autoridades laborales y las instituciones de seguridad social), no como empresarios ni empleadores, sino más bien como lo que en realidad son: trabajadores, operarios no subordinados, pero sí autónomos, que requieren de un trato jurídico especial y preferente, al igual que las empresas familiares y micro empresarios con hasta cuatro personas trabajando a su servicio.
} 


\section{EL DERECHO HUMANO AL TRABAJO DE LOS MIGRANTES. SU FUERZA JURÍDICA}

Todo individuo, tenga o no papeles que acrediten su legal estancia en el país al que migra en búsqueda de empleo, cuente o no con el permiso expreso del gobierno receptor que le autorice a laborar en su territorio, e incluso por ilegal que sea su internamiento en cualquier país, por el simple hecho de tratarse de una persona que tiene derechos humanos irrenunciables e inalienables que le siguen a donde quiera que vaya (portabilidad de derechos), merece ser tratado con humanidad y respeto a su dignidad como persona.

Después de todo, los orilla a migrar el hambre y la necesidad económica. ¿Y qué sabe el hambre de leyes? Además, no es fácil aventurarse y arriesgarse en todos sentidos por el sueño de una vida mejor, máxime cuando se marcha a un país de costumbres e idiosincrasia distinta, consciente que podrá ser discriminado por su aspecto y por no hablar el idioma, e incluso, ¿cuántos de ellos no saben siquiera leer ni escribir, ni efectuar operaciones aritméticas básicas?

Cierto, el problema humano es horrible y, sin embargo, como estas personas migran para trabajar, jurídicamente no están solas, así las autoridades de su país de origen no les atiendan ni tampoco lo hagan las del país receptor. Existen diversas normativas internacionales -convenios y recomendaciones de la OIT-, que les protegen vayan donde vayan y prohíben la discriminación en el empleo, entre ellos tres convenios internacionales, a saber:

- El Convenio 97, sobre los trabajadores migrantes (1949).

- El Convenio 111, sobre la discriminación (empleo y ocupación) (1958).

- El Convenio 143, sobre los trabajadores migrantes. Disposiciones complementarias (1975). ${ }^{15}$

\footnotetext{
${ }^{15}$ Véase la página electrónica de la OIT, http://www.seguridadcondemocracia.org/derechoshumanos/migracion-y-derechos-humanos/convenios-97-111-y-143-y-de-la-oit-sobre-los-
} 
El Convenio 143 -que es el más actual-, inicia con la siguiente afirmación: “Todo miembro para el cual se halle en vigor el presente Convenio se compromete a respetar los derechos humanos fundamentales de todos los trabajadores migrantes". ${ }^{16}$

Luego, tras reiterar que los trabajadores migrantes deben ingresar en el territorio nacional y ser admitidos al empleo, siempre de conformidad con la legislación pertinente del país que les recibe, el Convenio 143 precisa, en su artículo 9o., una serie de medidas que protegen de todas formas al migrante, señalando textualmente que:

En los casos en que dicha legislación no haya sido respetada y en los que su situación no pueda regularizarse, el trabajador migrante y su familia deberán disfrutar: a) De igualdad de trato en lo concerniente a los derechos derivados de empleos anteriores en materia de remuneración, seguridad en el empleo y otros beneficios. b) De la posibilidad de defender sus derechos ante un organismo competente, en caso de controversia sobre los derechos a que se refiere el párrafo anterior. c) De garantías para no correr con los costos de la expulsión, en el caso de que ésta se produzca. ${ }^{17}$

Por su parte, la Recomendación 151 de la OIT del mismo año 1975, parte del principio de que debe asegurarse: “...que los trabajadores migrantes y sus familias entren en el territorio nacional y sean admitidos al empleo con arreglo a la legislación pertinente"; y puntualmente advierte enseguida que, en el caso de que dicha legislación no haya sido respetada, debería tomarse

trabajadores-migrantes-y-la-no-discriminacion-laboral.htm/ (consultada el 10. de mayo de 2015).

16 Consultables en sitio web OIT, http://Www.ilo.org/dyn/norm/ex/es/f?p=NORMLEXPUB:12000:0::NO (consultada el 10. de mayo de 2015).

${ }^{17}$ Por cierto, el Convenio 143 puntualiza también que: “nada impedirá a los miembros la concesión a las personas que residen o trabajan de manera ilegal en el país del derecho a permanecer en él y ser legalmente empleadas" (artículo 9.4). Véase texto íntegro del Convenio núm. 143, adoptado por la OIT el 24 de junio de 1975, disponible en www.ilo.org. 
una decisión lo más pronto posible: “para que el trabajador migrante sepa si su situación puede ser regularizada".

Además, dicha Recomendación 151 de la OIT, insiste en los derechos que hemos recogido, reproduciendo en lo conducente el Convenio citado en último término y añadiendo sobre la igualdad de trato: “...en lo que se refiere a su sindicalización y al ejercicio de los derechos sindicales" (punto 8), y en lo que ahora más nos interesa destacar, la aludida Recomendación 151 (punto 34), textualmente señala lo siguiente:

1) Todo trabajador migrante que se marche del país de empleo debería tener derecho, independientemente de que su estancia en el país haya sido legal o no: a) a toda remuneración pendiente por trabajos realizados, incluidas las indemnizaciones por terminación de contrato normalmente pagaderas; $b$ ) a las prestaciones que se le debieren por concepto de accidente del trabajo o enfermedad profesional; c) según la práctica nacional: i) a una indemnización en concepto de vacaciones anuales devengadas pero no utilizadas; ii) al rembolso de las cotizaciones de seguridad social que, de acuerdo con la legislación nacional o los acuerdos internacionales, no den ni hayan dado lugar a derechos en su favor, en la inteligencia de que cuando las cotizaciones a la seguridad social no confieran derechos a prestaciones se debería hacer todo lo posible por concluir acuerdos bilaterales y multilaterales para proteger los derechos de los trabajadores migrantes. $\mathrm{Y}$,

2) En caso de desacuerdo sobre los derechos adquiridos por alguno de los conceptos previstos en el subpárrafo anterior, el trabajador deberá tener la posibilidad de hacer valer sus derechos ante el organismo competente y disfrutar de igualdad de trato en materia de asistencia judicial. ${ }^{18}$

Por último, en cuanto a los migrantes ilegales en clandestinidad, en los debates de 2004, la propia OIT ha llegado a considerar que: “...debe tenerse en cuenta la situación de los trabajadores migrantes irregulares y garantizarse que se protejan efectivamente sus derechos humanos y

18 Véase http://www.ilo.org/dyn/norm/ex/es/f?p=NORMLEXPUB:12100:0::NO:::P12100_ILO_ CODE:R151 (consultada el 10. de mayo de 2015). 
laborales fundamentales y que no sean objeto de explotación y trato arbitrario". ${ }^{19}$

Interesa señalar, a manera de colofón de todo lo dicho, que lo único cierto es que la OIT no se ha decidido a incluir todavía en ningún convenio o recomendación la imposible equiparación de los emigrantes legales y de los ilegales.

En tal contexto, la conclusión jurídica final no puede ser otra que el derecho a emigrar -mismo que está internacionalmente reconocido-, no está acompañado del derecho a inmigrar en ningún país sin el permiso expreso y soberano de éste; de manera entonces que se mantiene en ejercicio de la soberanía de cada país receptor de migrantes, su pleno derecho a admitir o no a extranjeros. Porque ya una vez admitidos legalmente los inmigrantes, éstos gozarán inequívocamente de los mismos derechos que los nacionales; en tanto que los inmigrantes irregulares o clandestinos tienen, como todo ser humano, un elemental derecho a la vida y a la asistencia sanitaria, a no ser torturado o sometido a castigos degradantes, a no prestar trabajo forzoso, a no ser detenido arbitrariamente, a que sea un juez quien le imponga cualquier sanción y a un juicio justo si se inicia un procedimiento penal anterior a su expulsión del país. ${ }^{20}$

Pero bien lo sabemos los juristas: las regulaciones legales, per se, no modifican los hechos ni alteran las preocupantes estadísticas migratorias actuales, porque a fin de cuentas la realidad suele ser más sabia y sobre todo más veloz que el derecho.

\footnotetext{
${ }^{19}$ Conclusión núm. 28, Trabajadores migrantes. Discusión general en un enfoque integrado, 92a. Reunión de la OIT, 16 junio 2004.

${ }^{20}$ A este respecto, el jurista ibérico Fernando Suárez González señala punzante: “No se ignora que la Corte Interamericana de Derechos Humanos pretende extender a los emigrantes indocumentados que entablan relaciones laborales los derechos que derivan de su condición de trabajador; pero hasta la fecha se trata de una opinión consultiva solicitada por México y emitida el 17 de septiembre de 2003". Gil y Gil, "Los trabajadores migrantes y la OIT", Relaciones Laborales, Madrid, núms. 15-16, agosto de 2009, p. 130.
} 


\section{A MANERA DE CONCLUSIÓN}

La historia misma de la humanidad hace puntual referencia a los grandes movimientos culturales, económicos, geográficos y políticos, que dieran origen a desplazamientos en masa de la población, tanto espontáneo como forzado, e interno como externo; múltiples migraciones han ocurrido desde épocas inmemoriales y por ende no se trata de un fenómeno nuevo, ni es tampoco de un tema poco analizado desde el ámbito científico. Acaso los juristas —en especial quienes cultivamos el derecho social—, sí que lo hemos ignorado por décadas, acaso porque la migración tiene diversas expresiones y es un tema complejo y de múltiples aristas, se migre o no para fines laborales.

Como ya hemos argumentado y demostrado jurídicamente, tanto la migración, como el trabajo, son derechos humanos inalienables e irrenunciables que deberían ser respetados en todo tiempo y lugar, existiendo incluso convenios internacionales, recomendaciones $y$ resoluciones de calado mundial que obligan a los Estados a regularle adecuadamente; empero, de no hacerlo, bien podrían utilizarse las poco estudiadas figuras jurídicas de los derechos sociales exigibles al Estado, así como la latencia de derechos en caso necesario.

Mediante tratados internacionales congruentes e inteligentes, debería pactarse la protección integral de los trabajadores migrantes mediante la regularización de su permanencia en el país receptor, a fin de que puedan ellos cobrar un salario justo y equitativo, pagando impuestos y aportando a la seguridad social igual, en similares términos que los empleados nacionales, para disfrutar sin discriminación alguna de la debida protección social que atañe al trabajo decente al ser derechos fundamentales del operario.

Asimismo, México debería promover ante la OIT que en futuras conferencias internacionales de este organismo rector del trabajo global, se retome con seriedad el tema de la migración laboral, exigiéndose en primer término que se cumplan los convenios internacionales y las recomendaciones existentes en la materia, sin que ello implique en modo alguno invasión a la 
soberanía nacional de los países miembros, y en segundo término, promoviendo que el derecho humano al trabajo migratorio sea protegido en todo tiempo y lugar, respetándose y amparándose a los migrantes cualquiera que sea su condición migratoria al tratarse de un tema humanitario que una sociedad que se precie de tener valores morales y éticos no puede ignorar pues en juego está la paz y el futuro del planeta.

A fin de cuentas, se trata es nada menos que reinterpretar el fenómeno de la globalización en todos sus órdenes, pero haciéndolo desde la perspectiva netamente humana. ¡Pues eso! 